\title{
Immediate, cumulative and residual effects of short- and long-term low plane of nutrition on milk protein and casein composition
}

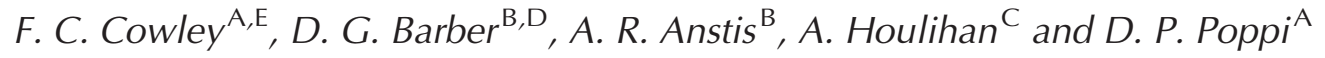

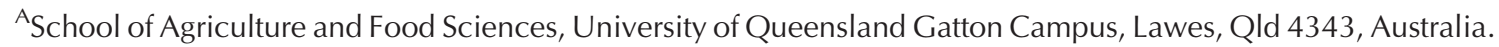 \\ ${ }^{B}$ Department of Agriculture, Fisheries and Forestry, University of Queensland Gatton Campus, Lawes, \\ Qld 4343, Australia.

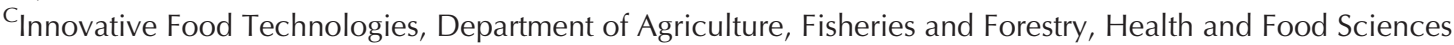 \\ Precinct, Coopers Plains, Brisbane, Qld 4108, Australia. \\ Deresent address: Parmalat Australia, Level 5, 35 Boundary Street, South Brisbane, Qld 4101, Australia. \\ ${ }^{E}$ Corresponding author. Email: f.cowley@uq.edu.au
}

\begin{abstract}
Immediate and residual effects of two lengths of low plane of nutrition (PON) on the synthesis of milk protein and protein fractions were studied at the Mutdapilly Research Station, in south-east Queensland. Thirty-six multiparous Holstein-Friesian cows, between 46 and 102 days in milk (DIM) initially, were used in a completely randomised design experiment with three treatments. All cows were fed on a basal diet of ryegrass pasture ( $7.0 \mathrm{~kg} \mathrm{DM} / \mathrm{cow}$.day), barley-sorghum concentrate mix $(2.7 \mathrm{~kg} \mathrm{DM} /$ cow.day) and a canola meal-mineral mix (1.3 kg DM/cow.day). To increase PON, $5.0 \mathrm{~kg}$ $\mathrm{DM} /$ cow.day supplemental maize and forage sorghum silage was added to the basal diet. The three treatments were (C) high PON (basal diet + supplemental silage); (L9) low PON (basal diet only) for a period of 9 weeks; and (L3) low PON (basal diet only) for a period of 3 weeks. The experiment comprised three periods (1) covariate - high PON, all groups (5 weeks), (2) period of low PON for either 3 weeks (L3) or 9 weeks (L9), and (3) period of high PON (all groups) to assess ability of cows to recover any production lost as a result of treatments ( 5 weeks). The low PON treatment periods for L3 and L9 were end-aligned so that all treatment groups began Period 3 together. Although there was a significant effect of L9 on yields of milk, protein, fat and lactose, and concentrations of true protein, whey protein and urea, these were not significantly different from L3. There were no residual effects of L3 or L9 on protein concentration or nitrogen distribution after 5 weeks of realimentation. There was no significant effect of low PON for 3 or 9 weeks on casein concentration or composition.
\end{abstract}

Additional keywords: pasture, silage, underfeeding, urea, whey protein.

Received 13 March 2014, accepted 29 May 2014, published online 24 July 2014

\section{Introduction}

The pasture-based dairy industry in Queensland experiences regular feed shortages during dry and transitional seasons (Cowan et al. 1998). These periods of low plane of nutrition (PON) coincide with periods of poor manufacturing quality milk (Houlihan et al. 2004). To compensate for reduced pasture availability, farmers rely heavily on silage as a supplementary feed (Cowan et al. 1998).

Milk protein concentration has been widely reported to decline with low energy intake (Coulon and Remond 1991; Murphy and O'Mara 1993; Coulon et al. 1998; Walker et al. 2004). Milk concentrations of casein and whey protein and even individual milk proteins are reportedly negatively affected by low PON (Gray and Mackenzie 1987; O'Brien et al. 1997; Mackle et al. 1999a). Little research so far has examined the response of casein number (the proportion of casein to true protein) or the individual caseins to changed nutrition. Although Coulon et al. (2001) did not find an effect of protein or energy supply on the relative proportions of the individual caseins, Mackle et al. (1999a) found an effect of PON on their concentrations in milk. If there is an effect of PON on the synthesis of the individual caseins, then the reversibility of any change would have implications for the manufacturing quality of milk.

Broster and Broster (1984) categorised the effects of changed PON as follows: immediate effect: the effects apparent in the first 3 weeks of the changed PON; cumulative effect: the effect of changed PON beyond the immediate effect; buffering effect: the ability of the cow to draw upon body reserves to maintain milk production despite reduced PON; residual effect: the continuation of the effects of changed PON after feeding of different rations has ceased and PON has returned to preexperimental levels; compensatory effect: above average performance upon return to high PON following a period of underfeeding.

It was hypothesised that (1) increased duration of underfeeding will significantly increase the cumulative effects of low PON on milk protein and casein composition, and 
(2) increased duration of underfeeding will significantly increase the residual effects of low PON on milk protein and casein concentration and composition.

\section{Materials and methods}

Cows and design

This experiment was conducted at the Mutdapilly Research Station (Department of Agriculture, Fisheries and Forestry, Queensland) in south-east Queensland (latitude $27^{\circ} 46^{\prime} \mathrm{S}$, longitude $152^{\circ} 40^{\prime} \mathrm{E}, 40 \mathrm{~m}$ above sea level). Thirty-three multiparous autumn-calved Holstein-Friesian cows, averaging 82 ( \pm 2.1 s.e.m.) days in milk (DIM), 558 ( \pm 7.9 s.e.m.) kg liveweight and 29 ( \pm 0.69 s.e.m.) kg/day milk yield (for lactation to date) initially, were used in a randomised block experiment with three treatments (11 cows each treatment), blocked on milk yield and then DIM. Before this experiment, all cows were managed in an extensive pasture plus partial mixed ration system, which provided a high PON.

The experiment was designed with three periods: (1) covariatehigh PON (pasture + silage) (all groups, 5 weeks), (2) period of low PON (pasture only) for either 3 weeks (L3) or 9 weeks (L9), and (3) period of high PON (pasture + silage) to assess ability of cows to recover any production lost as a result of treatments (5 weeks). The low PON treatment periods for L3 and L9 were end-aligned so that all treatment groups began Period 3 together. L3 continued on the high PON during the first 6 weeks of Period 2.

All cows were allocated a base diet of grazed ryegrass pasture at an allowance of $\sim 7 \mathrm{~kg} \mathrm{DM} /$ cow.day (grazed at night), barley-sorghum grain mix $(2.7 \mathrm{~kg} \mathrm{DM} /$ cow.day, fed in the dairy during the twice daily milking) and a canola mealmineral mix (1.3 kg DM/cow.day, fed in individual feed troughs). When not on a low PON as part of treatments, cows also received up to $5.0 \mathrm{~kg} \mathrm{DM} / \mathrm{cow}$.day of a mix of equal parts maize silage and forage sorghum silage (fed in individual feed troughs). This ration of silage was reviewed daily in conjunction with daily milk yield for each individual, and was designed to supplement their diet so that their daily milk yield was maintained at $\sim 20-25 \mathrm{~kg} / \mathrm{cow}$.day.

Overnight, all cows strip-grazed, as a group, a 9.7-ha ryegrass pasture, which had been split into six segments for grazing rotation. Total stocking rate was $5.6 \mathrm{cows} / \mathrm{ha}$. Pasture mass on offer and post-grazing residue was calculated daily using a rising plate meter, which was recalibrated for each grazing of each segment. An inaccessible pasture residue of $500 \mathrm{~kg} \mathrm{DM} / \mathrm{ha}$ was assumed. After morning milking, cows were detained in individual feedstalls for $\sim 3 \mathrm{~h}$, while the canola meal-mineral mix and supplementary silage were fed out, according to treatment group and experimental period (see below). Afterwards, cows were released onto a bare loafing area until afternoon milking.

Pluck samples of pasture were collected before grazing daily, and bulked for each grazing of each paddock segment. Silage, canola meal-mineral mix and grain mix were sampled weekly and bulked for Period 1, the first 6 weeks of Period 2, the second 3 weeks of Period 2 and Period 3. These pasture and feed samples were analysed for composition using either near-infrared spectroscopy or wet chemistry analytical methods, according to the Cornell Net Carbohydrate and Protein System at the DairyOne Forage Testing Laboratory (Ithaca, NY, USA).

Animal ethics approval was obtained for this experiment from the Department of Agriculture, Fisheries and Forestry, Queensland, under the Australian Code of Practice for the Care and Use of Animals for Scientific Purposes.

\section{Treatments}

In addition to the basal diet, high PON was imposed by the addition of a maize and forage sorghum silage mix, fed individually and calculated to achieve a $4-5 \mathrm{~kg}$ /day change in milk yield in individual cows using the NRC Dairy Cattle program (National Research Council 2001).

The three treatments were (C) high PON, basal diet + silage fed to achieve a daily milk yield of $20-25 \mathrm{~kg} /$ day $(\sim 5 \mathrm{~kg}$ DM silage/day), for the entirety of the experiment; (L9) silage removed (basal diet only only) for a period of 9 weeks in Period 2 to elicit a decrease in milk yield of $4-5 \mathrm{~kg}$; and (L3) silage removed (pasture only) for a period of 3 weeks at the end of Period 2 to elicit a decrease in milk yield of $4-5 \mathrm{~kg}$.

All treatments were subjected to a 5 -week covariate period (Period 1, Weeks 1-5) where a high PON (basal diet $+5 \mathrm{~kg} \mathrm{DM}$ silage/day) was maintained, adequate to achieve a daily milk yield of $20-25 \mathrm{~kg} /$ day. These feeding conditions continued throughout the course of the experiment for group $\mathrm{C}$ (19 weeks). To create a low PON, silage allowance was gradually removed from the L9 diet during Week 6 until milk yield had been reduced by $4-5 \mathrm{~kg} /$ day. This yield reduction required the removal of all silage. This diet was consumed by L9 cows for the remainder of Period 2. L3 cows remained on the same diet (high PON) as group C during Weeks 6-11 of Period 2. During Weeks 12-14 of Period 2, all silage was also removed from the L3 diet (immediately) to create a low PON, as in L9. The basal diet was maintained for all groups for the duration of the experiment. To prevent differential competition between treatment groups grazing the pasture, high and low PON groups grazed adjacent areas of similar pasture, separated by an electric fence. Another period of high PON for all groups followed immediately after Period 2, (Period 3, Weeks 15-19), to assess the residual effects of the treatments.

\section{Measurements}

A combined morning and evening milk sample (mixed in equal parts) was collected from individual cows weekly, except for the first 2 weeks after a change in PON when rapid variation in milk composition was expected, and samples were collected twice weekly (Monday and Wednesday). Where weekly milk samples were collected, half of the experimental herd was sampled on Monday, and the remaining cows sampled on Wednesday, due to laboratory capacity restrictions. Individual milking yields were recorded automatically by the Westfalia dairy management system. Liveweight was measured weekly after morning milking using Westfalia Taxatron walk-over scales. Individual body condition score was estimated weekly on a $1-8$ scale, with 1 being emaciated and 8 being obese (Robins et al. 2003). 
At the end of Periods 1, 2 and 3, jugular venous blood was collected from all cows and the plasma analysed for urea concentration (determined enzymatically by change in absorbance at $340 \mathrm{~nm}$ ), $\beta$-hydroxybutyrate (BOHB) and glucose concentrations [estimated using an automatic multitest analyser (Olympus Optical Co. Ltd, Tokyo, Japan)] and the serum analysed for non-esterified fatty acid (NEFA; WAKO Diagnostics, Richmond, VA, USA) concentration.

Milk samples were analysed by Fourier transform infrared techniques (Foss Milko-Scan FT120, Hillerød, Denmark) for the concentrations of fat, total nitrogen, true protein and casein. Whey protein was calculated by difference (Auldist et al. 2010). Lactose was determined by difference (Auldist et al. 2010). Urea analyses were conducted using the urea colourimetric method of Bergmeyer et al. (1985). Samples were analysed for milk casein composition $\left(\alpha_{\mathrm{s} 1^{-}}, \alpha_{\mathrm{s} 2^{-}}, \beta\right.$ - and $\kappa$-casein concentrations and proportions) using a Shimadzu LC-10 analytical reverse phase HPLC (Shimadzu, Kyoto,

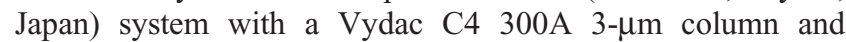
gradient elution using acetonitrile/TFA (Visser et al. 1991; Auldist et al. 2010). Mean response coefficients were used to determine mass fractions of individual protein components relative to total casein in the test samples (Groen et al. 1994; Auldist et al. 2010).

Statistical analysis was by 1.s.d. constructed from regression model extension (GENSTAT Release 8.0, VSNi, Hemel Hempstead, UK). Comparisons were made between the treatment groups at the end of the first 3 weeks of Period 2, the end of Period 2, and the end of Period 3. Final values for each these periods were used for liveweight, yield of milk,

Table 1. Effect of constant high plane of nutrition (PON) (C) or low PON for 3 (L3) or 9 (L9) weeks on period final values for yields of milk and milk components, and liveweights during a covariate period of high PON (Period 1), a period of low PON (Period 2; Weeks 6-12: L9 only, Weeks 12-14: L3 and L9) and a realimentation period of high PON (Period 3) All analysed with mean of Period 1 as a covariate (except the comparison of Weeks 8 and 14). Values within a row followed by different letters are significantly different. n.s., not significant

\begin{tabular}{|c|c|c|c|c|}
\hline \multirow[t]{2}{*}{ Period } & \multicolumn{3}{|c|}{ Treatment group } & \multirow[t]{2}{*}{$P$-value } \\
\hline & $\mathrm{C}$ & L3 & L9 & \\
\hline \multicolumn{5}{|c|}{ Milk yield (L/day) } \\
\hline Period 1 (mean, Weeks 1-5) & $27.3 \pm 1.03$ & $26.7 \pm 1.03$ & $26.9 \pm 1.03$ & n.s. \\
\hline Period 2 (final, Week 8) & $24.5 \mathrm{a} \pm 0.49$ & $24.8 \mathrm{a} \pm 0.49$ & $22.2 b \pm 0.49$ & $* * *$ \\
\hline Period 2 (final, Week 14) & $23.2 \mathrm{a} \pm$ & $18.6 \mathrm{~b} \pm$ & $18.3 b \pm$ & $* * *$ \\
\hline $\begin{array}{l}\text { Period } 2 \text { [final, Week } 8 \\
\text { (L9) vs Week } 14 \text { (L3)] }\end{array}$ & - & $18.4 \mathrm{a} \pm 0.49$ & $22.1 \mathrm{~b} \pm 0.49$ & $* * *$ \\
\hline Period 3 (final, Week 19) & $20.9 \mathrm{a} \pm 0.44$ & $20.2 \mathrm{a} \pm 0.44$ & $18.5 b \pm 0.44$ & $* *$ \\
\hline \multicolumn{5}{|c|}{ Milk protein yield (g/day) } \\
\hline Period 1 (mean, Weeks 1-5) & $811 \pm 42.3$ & $803 \pm 42.3$ & $839 \pm 42.3$ & n.s. \\
\hline Period 2 (final, Week 8) & $846 \mathrm{a} \pm 34.5$ & $795 \mathrm{a} \pm 34.6$ & $701 b \pm 25.4$ & $* *$ \\
\hline Period 2 (final, Week 14) & $782 \mathrm{a} \pm 23.6$ & $632 b \pm 23.9$ & $617 \mathrm{~b} \pm 23.9$ & $* * *$ \\
\hline $\begin{array}{l}\text { Period } 2 \text { [final, Week } 8 \\
\text { (L9) vs Week } 14 \text { (L3)] }\end{array}$ & - & $576 \mathrm{a} \pm 21.2$ & $701 \mathrm{~b} \pm 21.1$ & n.s. \\
\hline Period 3 (final, Week 19) & $691 \mathrm{a} \pm 16.2$ & $680 \mathrm{a} \pm 16.4$ & $617 b \pm 16.5$ & $* *$ \\
\hline \multicolumn{5}{|c|}{ Milk fat yield ( $g /$ day) } \\
\hline Period 1 (mean, Weeks 1-5) & $1165 \pm 68.5$ & $1080 \pm 68.5$ & $1178 \pm 68.5$ & n.s. \\
\hline Period 2 (final, Week 8) & $1180 \mathrm{a} \pm 36.5$ & $1058 b \pm 36.3$ & $883 \mathrm{c} \pm 26.8$ & $*$ \\
\hline Period 2 (final, Week 14) & $1020 \mathrm{a} \pm 78.8$ & $855 b \pm 58.7$ & $767 \mathrm{~b} \pm 53.1$ & $* *$ \\
\hline $\begin{array}{l}\text { Period } 2 \text { [final, Week } 8 \\
\text { (L9) vs Week } 14 \text { (L3)] }\end{array}$ & - & $814 \pm 23.1$ & $890 \pm 22.9$ & n.s. \\
\hline Period 3 (final, Week 19) & $897 \mathrm{a} \pm 19.5$ & $858 \mathrm{a} \pm 19.9$ & $787 b \pm 19.6$ & $* *$ \\
\hline \multicolumn{5}{|c|}{ Milk lactose yield (g/day) } \\
\hline Period 1 (mean, Weeks 1-5) & $1379 \pm 85.1$ & $1340 \pm 85.1$ & $1402 \pm 85.1$ & n.s. \\
\hline Period 2 (final, Week 8) & $1318 \mathrm{a} \pm 37.2$ & $1281 \mathrm{a} \pm 37.6$ & $1117 \mathrm{~b} \pm 27.5$ & $* * *$ \\
\hline Period 2 (final, Week 14) & $1093 \mathrm{a} \pm 38.4$ & $907 \mathrm{~b} \pm 38.5$ & $967 b \pm 38.5$ & $* * *$ \\
\hline $\begin{array}{l}\text { Period } 2 \text { [final, Week } 8 \\
\text { (L9) vs Week } 14 \text { (L3)] }\end{array}$ & - & $890 \mathrm{a} \pm 32.4$ & $1101 b \pm 32.3$ & $* * *$ \\
\hline Period 3 (final, Week 19) & $1028 \mathrm{a} \pm 24.6$ & $997 \mathrm{a} \pm 24.9$ & $903 b \pm 24.8$ & $* *$ \\
\hline \multicolumn{5}{|c|}{ Liveweight $(\mathrm{kg})$} \\
\hline Period 1 (mean, Weeks 1-5) & $555 \pm 15.4$ & $538 \pm 20.5$ & $555 \pm 13.5$ & n.s. \\
\hline Period 2 (final, Week 8) & $554 \mathrm{ab} \pm 4.3$ & $563 \mathrm{a} \pm 4.4$ & $548 \mathrm{ab} \pm 4.3$ & $* * *$ \\
\hline Period 2 (final, Week 14) & $554 \mathrm{a} \pm 4.0$ & $536 \mathrm{~b} \pm 4.0$ & $528 \mathrm{~b} \pm 4.0$ & $* * *$ \\
\hline $\begin{array}{l}\text { Period } 2 \text { [final, Week } 8 \\
\text { (L9) vs Week } 14 \text { (L3)] }\end{array}$ & - & $525 \pm 13.9$ & $556 \pm 13.9$ & n.s. \\
\hline Period 3 (final, Week 19) & $570 \pm 3.8$ & $561 \pm 3.8$ & $565 \pm 3.8$ & n.s. \\
\hline
\end{tabular}


protein, fat and lactose, and nitrogen distribution. Because of the split day milk sampling schedule, final values were calculated from a linear regression of each period, fitted for each cow with a constant, the parameter mean for each sample day during the period for each treatment, and the number of samples contributing to the mean. The analysis of the regression was by accumulated ANOVA of regression analysis, fitted with a constant, treatment (L3 and L9) and the mean of Period 1 as a covariate. To compare the immediate effects of a change to low PON between the two low PON treatments, the calculated final value from first 3 weeks of low PON for L9 was compared with the calculated final value from the period of low PON for L3 by simple ANOVA fitted with a constant and treatment only. A similar analysis was used for casein composition, however, due to large between- sample day variation, significant lines could not be fitted for all casein mass fractions, and mean values for these periods were reported instead. Change of milk yield between periods for group C was by Student's $t$-test.

\section{Results and discussion}

Immediate and cumulative effects of low PON

Group $\mathrm{C}$ cows demonstrated $\sim 25 \%$ decline in milk yield over the 19 weeks of the experiment $(P<0.001)$ (Table 1$)$. This is likely an effect of stage of lactation (SOL), although other seasonal factors such as maturation of the pasture and weather conditions may have also contributed to changes in yields and composition in group C. Low PON caused a significant reduction in milk yield in Period 2 for groups L9 and L3, as

Table 2. Effect of constant high plane of nutrition (PON) (C) or low PON for 3 (L3) or 9 (L9) weeks on period final values for protein concentration and nitrogen distribution, during a covariate period of high PON (Period 1), a period of low PON (Period 2; Weeks 6-12: L9 only, Weeks 12-14: L3 and L9) and a realimentation period of high PON (Period 3) All analysed with mean of Period 1 as a covariate, (except the comparison of Weeks 8 and 14). Values within a row followed by different letters are significantly differenct. n.s., not significant

\begin{tabular}{|c|c|c|c|c|}
\hline \multirow[t]{2}{*}{ Period } & \multicolumn{3}{|c|}{ Treatment group } & \multirow[t]{2}{*}{$P$-value } \\
\hline & $\mathrm{C}$ & L3 & L9 & \\
\hline \multicolumn{5}{|c|}{ True protein $(\%, m / v)$} \\
\hline Period 1 (mean, Weeks 1-5) & $3.00 \pm 0.08$ & $2.98 \pm 0.08$ & $3.07 \pm 0.08$ & n.s. \\
\hline Period 2 (final, Week 8) & $3.17 \mathrm{a} \pm 0.03$ & $3.20 \mathrm{a} \pm 0.03$ & $3.05 b \pm 0.02$ & $* *$ \\
\hline Period 2 (final, Week 14) & $3.14 \mathrm{a} \pm 0.04$ & $3.08 \mathrm{ab} \pm 0.04$ & $3.02 b \pm 0.04$ & $*$ \\
\hline $\begin{array}{l}\text { Period } 2 \text { [final, Week } 8 \\
\text { (L9) vs Week } 14 \text { (L3)] }\end{array}$ & - & $3.05 \pm 0.03$ & $3.08 \pm 0.03$ & n.s. \\
\hline Period 3 (final, Week 19) & $3.26 \pm 0.05$ & $3.36 \pm 0.05$ & $3.28 \pm 0.05$ & n.s. \\
\hline \multicolumn{5}{|c|}{ Casein $(\%, m / v)$} \\
\hline Period 1 (mean, Weeks 1-5) & $2.52 \pm 0.07$ & $2.50 \pm 0.07$ & $2.56 \pm 0.07$ & n.s. \\
\hline Period 2 (final, Week 8) & $2.63 \mathrm{a} \pm 0.03$ & $2.64 \mathrm{a} \pm 0.03$ & $2.53 b \pm 0.02$ & $* *$ \\
\hline Period 2 (final, Week 14) & $2.59 \pm 0.03$ & $2.56 \pm 0.03$ & $2.51 \pm 0.03$ & n.s. \\
\hline $\begin{array}{l}\text { Period } 2 \text { [final, Week } 8 \\
\text { (L9) vs Week } 14 \text { (L3)] }\end{array}$ & - & $2.53 \pm 0.02$ & $2.55 \pm 0.02$ & n.s. \\
\hline Period 3 (final, Week 19) & $2.70 \pm 0.04$ & $2.77 \pm 0.04$ & $2.71 \pm 0.04$ & n.s. \\
\hline \multicolumn{5}{|c|}{ Casein number } \\
\hline Period 1 (mean, Weeks 1-5) & $83.8 \pm 0.37$ & $84.0 \pm 0.37$ & $83.4 \pm 0.37$ & n.s. \\
\hline Period 2 (final, Week 8) & $82.8 \pm 0.33$ & $82.7 \pm 0.34$ & $82.9 \pm 0.25$ & n.s. \\
\hline Period 2 (final, Week 14) & $82.6 \pm 0.25$ & $83.0 \pm 0.25$ & $83.0 \pm 0.25$ & n.s. \\
\hline $\begin{array}{l}\text { Period } 2 \text { [final, Week } 8 \\
\text { (L9) vs Week } 14 \text { (L3)] }\end{array}$ & - & $83.2 \pm 0.26$ & $82.7 \pm 0.27$ & n.s. \\
\hline Period 3 (final, Week 19) & $82.8 \pm 0.30$ & $82.3 \pm 0.31$ & $82.3 \pm 0.31$ & n.s. \\
\hline \multicolumn{5}{|c|}{ Whey protein $(\%, m / v)$} \\
\hline Period 1 (mean, Weeks 1-5) & $0.49 \pm 0.021$ & $0.48 \pm 0.021$ & $0.52 \pm 0.021$ & n.s. \\
\hline Period 2 (final, Week 8) & $0.55 \mathrm{ab} \pm 0.014$ & $0.56 \mathrm{a} \pm 0.015$ & $0.53 b \pm 0.011$ & $*$ \\
\hline Period 2 (final, Week 14) & $0.55 \mathrm{a} \pm 0.010$ & $0.53 \mathrm{ab} \pm 0.010$ & $0.52 b \pm 0.011$ & $*$ \\
\hline $\begin{array}{l}\text { Period } 2 \text { [final, Week } 8 \\
\text { (L9) vs Week } 14 \text { (L3)] }\end{array}$ & - & $0.52 \pm 0.011$ & $0.54 \pm 0.011$ & n.s. \\
\hline Period 3 (final, Week 19) & $0.57 \pm 0.014$ & $0.60 \pm 0.014$ & $0.59 \pm 0.014$ & n.s. \\
\hline \multicolumn{5}{|c|}{ Urea $(\%, m / v)$} \\
\hline Period 1 (mean, Weeks 1-5) & $0.035 \pm 0.0020$ & $0.034 \pm 0.0020$ & $0.033 \pm 0.0020$ & n.s. \\
\hline Period 2 (final, Week 8) & $0.035 \mathrm{a} \pm 0.0029$ & $0.034 \mathrm{a} \pm 0.0029$ & $0.047 b \pm 0.0021$ & $* *$ \\
\hline Period 2 (final, Week 14) & $0.034 \mathrm{a} \pm 0.0017$ & $0.046 b \pm 0.0016$ & $0.045 b \pm 0.0017$ & $* * *$ \\
\hline $\begin{array}{l}\text { Period } 2 \text { [final, Week } 8 \\
\text { (L9) vs Week } 14 \text { (L3)] }\end{array}$ & - & $0.046 b \pm 0.0018$ & $0.047 \mathrm{~b} \pm 0.0018$ & $* *$ \\
\hline Period 3 (final, Week 19) & $0.026 \pm 0.0015$ & $0.027 \pm 0.0015$ & $0.028 \pm 0.0015$ & n.s. \\
\hline
\end{tabular}


compared with group $\mathrm{C}$. This downregulation of the mammary gland had immediate negative effects on yields of protein, fat and lactose for L9 and L3 (Table 1). However, there was no additional cumulative effect beyond the immediate effect of low PON on these parameters, as evidenced by no significant difference between L3 and L9 at the end of Period 2. Yields of milk, protein and lactose were all significantly lower in L3 at the end of the 3 weeks of low PON than at the end of the first 3 weeks of low PON in the L9 group. This, as in milk yield, is likely an effect of SOL or factors confounding with SOL, as group $\mathrm{C}$ displayed substantial changes in all parameters over the duration of the experiment. Both L3 and L9 lost liveweight while on a low PON; however, L9 liveweight did not become significantly different from $\mathrm{C}$ until the end of Period 2 (Table 1). Low PON caused a similar loss of liveweight in L3 and L9. There was little variation in BCS and no significant effect of treatment.

Immediate effects of low PON on the concentrations of true protein, casein, and urea were evident after 3 weeks in L9, with reduced protein concentrations and increased urea concentration, compared with $\mathrm{C}$ (Table 2). As for yields of milk and milk components, there was substantial change in the concentrations of true protein, casein, whey protein and urea in group $\mathrm{C}$ over the duration of the experiment (Table 2). An immediate effect of L3 was evident at the end of Period 2 in increased urea concentration, but reduced concentrations of true protein and whey protein were intermediate between L9 and C, and not significantly different from either. L9 displayed significant reductions in true protein and whey protein concentrations compared with $\mathrm{C}$ at the end of Period 2, although these were not significantly different from L3 at that time. These indistinct results are difficult to clearly attribute to cumulative effects, as they may be a continuation of the immediate effects reported above. Casein concentration and casein number showed no effect of either duration of low PON at the end of Period 2. This agrees with previous reports of the resilience of casein number to the effects of changed PON, as reported in Coulon et al. (2001). However, low PON has previously been shown to cause significant reductions in casein and whey protein concentrations (Kefford et al. 1995; Petch et al. 1997; Mackle et al. 1999a; Thomson et al. 2001) and casein number (Kefford et al. 1995; Lacy-Hulbert et al. 1999;

Table 3. Effect of constant high plane of nutrition (PON) (C) or low PON for 3 (L3) or 9 (L9) weeks on mean casein mass fractions (relative casein proportions with weight of that casein fraction expressed as a proportion of total casein weight) during a covariate period of high PON (Period 1), a period of low PON (Period 2; Weeks 6-12: L9 only, Weeks 12-14: L3 and L9) and a realimentation period of high PON (Period 3)

All analysed with Period 1 as a covariate, except the comparison of Weeks 6-8 and 12-14). Values within a row followed by different are significantly different. n.s., not significant

\begin{tabular}{|c|c|c|c|c|}
\hline \multirow[t]{2}{*}{ Casein mass fraction } & \multicolumn{3}{|c|}{ Treatment group } & \multirow[t]{2}{*}{$P$-valu } \\
\hline & $\mathrm{C}$ & L3 & L9 & \\
\hline \multicolumn{5}{|c|}{$\alpha_{S 1}{ }^{- \text {casein mass fraction }}$} \\
\hline Period 1 (mean, Weeks 1-5) & $0.35 \pm 0.005$ & $0.35 \pm 0.005$ & $0.35 \pm 0.005$ & n.s. \\
\hline Period 2 (mean, Weeks 6-8) & $0.36 \pm 0.003$ & $0.36 \pm 0.003$ & $0.36 \pm 0.002$ & n.s. \\
\hline Period 2 (mean, Weeks 6-14) & $0.34 \pm 0.003$ & $0.35 \pm 0.003$ & $0.35 \pm 0.003$ & n.s. \\
\hline $\begin{array}{l}\text { Period } 2 \text { [mean, Weeks 6-8 } \\
\text { (L9) vs Weeks 12-14 (L3)] }\end{array}$ & - & $0.35 \pm 0.004$ & $0.36 \pm 0.004$ & n.s. \\
\hline Period 3 (mean, Weeks 15-19) & $0.33 \pm 0.002$ & $0.33 \pm 0.002$ & $0.33 \pm 0.002$ & n.s. \\
\hline \multicolumn{5}{|c|}{$\alpha_{S 2}$-casein mass fraction } \\
\hline Period 1 (mean, Weeks 1-5) & $0.14 \pm 0.005$ & $0.14 \pm 0.005$ & $0.14 \pm 0.005$ & n.s. \\
\hline Period 2 (mean, Weeks 6-8) & $0.15 \pm 0.002$ & $0.14 \pm 0.002$ & $0.14 \pm 0.002$ & n.s. \\
\hline Period 2 (mean, Weeks 6-14) & $0.13 \pm 0.002$ & $0.13 \pm 0.002$ & $0.13 \pm 0.002$ & n.s. \\
\hline $\begin{array}{l}\text { Period } 2 \text { [mean, Weeks 6-8 } \\
\text { (L9) vs Weeks 12-14 (L3)] }\end{array}$ & - & $0.13 \pm 0.002$ & $0.13 \pm 0.002$ & n.s. \\
\hline Period 3 (mean, Weeks 15-19) & $0.14 \pm 0.002$ & $0.13 \pm 0.002$ & $0.14 \pm 0.002$ & n.s. \\
\hline \multicolumn{5}{|c|}{$\beta$-casein mass fraction } \\
\hline Period 1 (mean, Weeks 1-5) & $0.41 \pm 0.005$ & $0.40 \pm 0.005$ & $0.40 \pm 0.005$ & n.s. \\
\hline Period 2 (mean, Weeks 6-8) & $0.39 \pm 0.003$ & $0.39 \pm 0.003$ & $0.39 \pm 0.002$ & n.s. \\
\hline Period 2 (mean, Weeks 6-14) & $0.43 \pm 0.003$ & $0.43 \pm 0.003$ & $0.43 \pm 0.003$ & n.s. \\
\hline $\begin{array}{l}\text { Period } 2 \text { [mean, Weeks 6-8 } \\
\text { (L9) vs Weeks 6-14 (L3)] }\end{array}$ & - & $0.43 \mathrm{a} \pm 0.003$ & $0.39 b \pm 0.003$ & $* * *$ \\
\hline Period 3 (mean, Weeks 15-19) & $0.44 \mathrm{a} \pm 0.002$ & $0.44 \mathrm{a} \pm 0.002$ & $0.43 b \pm 0.002$ & $* * *$ \\
\hline \multicolumn{5}{|c|}{$\kappa$-casein mass fraction } \\
\hline Period 1 (mean, Weeks 1-5) & $0.11 \pm 0.004$ & $0.11 \pm 0.004$ & $0.11 \pm 0.004$ & n.s. \\
\hline Period 2 (mean, Weeks 6-8) & $0.11 \pm 0.002$ & $0.11 \pm 0.002$ & $0.11 \pm 0.001$ & n.s. \\
\hline Period 2 (mean, Weeks 6-14) & $0.10 \pm 0.003$ & $0.09 \pm 0.003$ & $0.10 \pm 0.003$ & n.s. \\
\hline $\begin{array}{l}\text { Period } 2 \text { [mean, Weeks 6-8 } \\
\text { (L9) vs Weeks 6-14 (L3)] }\end{array}$ & - & $0.10 \mathrm{a} \pm 0.003$ & $0.11 b \pm 0.003$ & $* * *$ \\
\hline Period 3 (mean, Weeks 15-19) & $0.10 \mathrm{a} \pm 0.002$ & $0.09 b \pm 0.002$ & $0.10 \mathrm{a} \pm 0.002$ & $* * *$ \\
\hline
\end{tabular}


Mackle et al. 1999a) as well as true protein concentrations (O’Brien et al. 1997; Petch et al. 1997; Mackle et al. 1999a).

The different immediate effects observed in L3 and L9 may due to differences in the susceptibility of the cow to changes in nutrition at different stage of lactation, or effects of advancing seasonal change (there was a 6-week difference in start dates of each low PON). Although true protein, casein and whey protein concentrations showed generally upward trends in group $\mathrm{C}$ over the course of the experiment, results from Week 3 of L9's low PON period showed an upward spike in these parameters in both $\mathrm{C}$ and L3. It is possible that there was some variation in the nutritional composition of the silage at that point which affected both silage-fed groups, although the bulked period samples show no substantial variation (data not shown).

One interpretation of the significant negative effects of low PON on the yield of milk protein, fat and lactose in this experiment is that they are collectively driven by the general downregulation of milk production (specifically, milk yield), rather than any specific action on the synthesis of those constituents themselves (i.e. concentration in milk) (LacyHulbert et al. 1999). However, it would have been expected that a simple decrease in milk yield would have caused an increase in milk protein concentration from the concentrating effect of milk yield. Instead, in the L9 group, true protein concentration was significantly decreased under the effects of low PON. This effect was not seen in L3. The low PON in L9 significantly affected milk composition indicating that the synthesis of protein was actively downregulated in response to nutrition. A similar effect was likely in action on lactose concentration, which would have driven the change in milk yield.

There were no immediate or cumulative effects of low PON on casein composition (Table 3). Casein mass fractions tended to vary in the same way across all treatments in this experiment, and between sample day variation exceeded variation attributable to treatments (data not shown). There are indications in the literature that mammary synthesis of individual proteins may be affected by low PON. Comparing restricted pasture intake with unrestricted pasture supplemented with a concentrate, Mackle et al. (1999a) observed a positive correlation of feeding level with milk concentrations $(\mathrm{g} / \mathrm{kg})$ of $\alpha-, \beta-, \kappa-$ and $\gamma$-caseins (at 60 and 180 DIM). At 203 DIM, however, those authors could not identify a positive effect of supplementation on milk concentrations of the mammary-synthesised proteins (Mackle et al. 1999b), which may indicate a role for SOL. In a 4-week experiment with small sample numbers, Coulon et al. (2001) could find no role for changing level of energy and protein supply in the mass fractions of the individual caseins.

By the end of the period of low PON, both L3 and L9 were demonstrating increased plasma urea $[\mathrm{C}=3.99 \mathrm{mmol} / \mathrm{L}, \mathrm{L3}=$ $6.55 \mathrm{mmol} / \mathrm{L}, \mathrm{L} 9=6.45 \mathrm{mmol} / \mathrm{L}(P<0.01)]$ and $\mathrm{BOHB}[\mathrm{C}=0.28$ $\mathrm{mmol} / \mathrm{L}, \mathrm{L} 3=0.48 \mathrm{mmol} / \mathrm{L}, \mathrm{L} 9=0.48 \mathrm{mmol} / \mathrm{L}(P=0.01)]$ concentrations, compared with $\mathrm{C}$. Increased milk urea concentration in low PON groups was consistent with their elevated plasma urea concentrations (Mackle et al. 1999a, $1999 b$ ). This may have come from the mobilisation of dietary and endogenous protein sources for gluconeogenesis, or reduced incorporation of rumen ammonia into milk protein as a result of insufficient dietary ME intake. There were no effects of treatment on plasma glucose or serum NEFA concentrations.

\section{Residual and compensatory effects of low PON}

Once PON was increased in Period 3, L3 cows increased their yields of milk, protein, fat and lactose, so that by the period end there were no longer any differences from $\mathrm{C}$ (Table 1$)$. However, L9 milk yield remained lower than $\mathrm{C}$ (Table 1). There were also residual effects of L9 on protein, fat and lactose yields in Period 3 (Table 1) but no residual effects of L3 or L9 on nitrogen distribution (Table 2). Grainger and Wilhelms (1979) reported significant residual effects on protein and fat yields for the remainder of lactation for a 10-week low PON treatment in early lactation but not a 5-week low PON. Rohrmoser and Kirchgessner (1982) reported that after a 4-week energy-restricted diet was returned to pre-restriction levels, mid-lactation milk protein concentration rapidly returned to pre-restriction levels and showed no significant difference from a control group following a 3-week period of realimentation. It may be that the residual effect of low PON is greater in early lactation than in mid-lactation cows, as in this experiment.

Cows within all treatment groups (C, L3 and L9) gained weight during Period 3 (Table 1), although a compensatory effect on rate of gain over Period 3 was evident in groups L3 $(1.08 \mathrm{~kg} /$ day $)$ and L9 (1.25 kg/day) compared with group C (0.71 $\mathrm{kg}$ /day) $(P<0.01)$, resulting in no significant difference in liveweights for Period 3. The strong influence of SOL, as evidenced by the declining yields of group $\mathrm{C}$, would also appear to limit the potential for any improvement in milk yield at this point in the lactation (cows averaged 183 DIM at the start of Period 3). Furthermore, there would also seem to be a preferential partitioning of energy towards liveweight gain in Period 3, rather than milk production. Although the $\beta$ - and $\kappa$-casein mass fractions of L9 were elevated in Period 3 (Table 3), this was not attributable to any residual effects of low PON.

This experiment was designed to investigate the ability to recover milk protein production following a nutritional challenge of varying time period, in addition to the immediate and/or cumulative effects of a low PON. Although there were immediate effects of low PON for 3 weeks on milk, protein, fat and lactose yields, and protein, casein, whey and urea concentrations, there were no additional cumulative effects of 9 weeks of low PON. Despite some changes in protein synthesis and composition, no effect of PON could be found on casein composition. While there were residual effects of L9 on yields on milk, protein, fat and lactose, there were no residual effects of either duration of underfeeding on protein or casein composition after 5 weeks of realimentation. These findings emphasise the importance of providing supplemental feed during periods of extended pasture shortage, if yields are not to be irreparably affected, even when feed availability improves. However, the low PON in this experiment did not cause longlasting effects on protein composition. Furthermore, this experiment provides new evidence that casein number and casein composition are not susceptible to the effects of changed PON.

\section{Acknowledgements}

The authors thank Dairy Australia for funding this work. We are grateful to Pat Pepper for assistance with the design and statistical analysis of this experiment, and to Natalie Spiller for her skilled technical assistance. 


\section{References}

Auldist MJ, Grainger C, Houlihan AV, Mayes JJ, Williams RPW (2010) Composition, coagulation properties, and cheesemaking potential of milk from cows undergoing extended lactations in a pasture-based dairying system. Journal of Dairy Science 93, 1401-1411. doi:10.3168/jds.2009-2727

Bergmeyer HU, Bergmeyer J, Grassl M (Eds) (1985) 'Methods of enzymatic analysis. Metabolites 3: lipids, amino acids and related compounds.' (VCH Publications: New York)

Broster WH, Broster VJ (1984) Reviews of the progress of dairy science: long term effects of plane of nutrition on the performance of the dairy cow. The Journal of Dairy Research 51, 149-196. doi:10.1017/S002202 9900023414

Coulon JB, Remond B (1991) Variations in milk output and milk protein content in response to the level of energy supply to the dairy cow: a review. Livestock Production Science 29, 31-47. doi:10.1016/0301-6226(91) 90118-A

Coulon JB, Hurtaud C, Remond B, Verite R (1998) Factors contributing to variation in the proportion of casein in cow's milk true protein: a review of recent INRA experiments. The Journal of Dairy Research 65, 375-387. doi: $10.1017 /$ S0022029998002866

Coulon JB, DuPont D, Pochet S, Pradel P, DuPloyer H(2001) Effect of genetic potential and level of feeding on milk protein composition. The Journal of Dairy Research 68, 569-577. doi:10.1017/S002202990100512X

Cowan RT, Moss RJ, Goodwin PG, Fulkerson WJ (1998) Efficiency in feeding systems for subtropical dairy production. In 'Animal production in Australia: proceedings of the Australian Society of Animal Production', 22nd biennial conference, University of New England, Armidale, New South Wales, Australia, 20-24 April 1998. 22, 125-128.

Grainger C, Wilhelms G (1979) Effect of duration and pattern of underfeeding in early lactation on milk production and reproduction of dairy cows. Australian Journal of Experimental Agriculture and Animal Husbandry 19, 395-401. doi:10.1071/EA9790395

Gray RM, Mackenzie DDS (1987) Effect of plane of nutrition on the concentration and yield of whey proteins in bovine milk. New Zealand Journal of Dairy Science and Technology 22, 157-165.

Groen AF, van der Vegt R, van Boekel MAJS, de Rouw OLAM, Vos H(1994) Case study on individual animal variation in milk protein composition as estimated by high-pressure liquid chromatography. Netherlands Milk and Dairy Journal 48, 201-212.

Houlihan A, Barber DG, Deeth H, Cowan RT (2004) The influence of tropical feeding on the processability of milk (DAQ180). In 'Milk protein: level, composition and processability'. Final combined report to Dairy Australia on projects: UQ062 Managing milk protein levels in dairy cows; UQ11161 Nutritional manipulation of milk protein concentration, composition and processability; DAQ180 The influence of tropical feeding of the processability of milk; DAQ11287 Milk characterisation for functionality indication. (Ed. DP Poppi) pp. 83-111. (University of Queensland: Brisbane)
Kefford B, Christian MP, Sutherland BJ, Mayes JJ, Grainger C (1995) Seasonal influences on Cheddar cheese manufacture: influence of diet quality and stage of lactation. The Journal of Dairy Research 62, 529-537. doi:10.1017/S0022029900031228

Lacy-Hulbert SJ, Woolford MW, Nicholas GD, Prosser CG, Stelwagen K (1999) Effect of milking frequency and pasture intake on milk yield and composition of late lactation cows. Journal of Dairy Science 82, 1232-1239. doi:10.3168/jds.S0022-0302(99)75346-4

Mackle TR, Bryant AM, Petch SF, Hill JP, Auldist MJ (1999a) Nutritional influences on the composition of milk from cows of different protein phenotypes in New Zealand. Journal of Dairy Science 82, 172-180. doi:10.3168/jds.S0022-0302(99)75221-5

Mackle TR, Bryant AM, Petch SF, Hooper RJ, Auldist MJ (1999b) Variation in the composition of milk protein from pasture-fed dairy cows in late lactation and the effect of grain and silage supplementation. New Zealand Journal of Agricultural Research 42, 147-154. doi:10.1080/00288233. 1999.9513364

Murphy JJ, O’Mara F (1993) Nutritional manipulation of milk protein concentration and its impact on the dairy industry. Livestock Production Science 35, 117-134. doi:10.1016/0301-6226(93)90185-K

National Research Council (2001) 'Nutrient requirements of dairy cattle. Computer model program for predicting nutrient requirements.' (National Academy Press: Washington, DC)

O'Brien B, Murphy JJ, Connolly JF, Mehra R, Guinee TP, Stakelum G (1997) Effect of altering and daily herbage allowance in mid lactation on the composition and processing characteristics of bovine milk. The Journal of Dairy Research 64, 621-626. doi:10.1017/S0022029997002513

Petch SF, Bryant AM, Napper AR (1997) Effects of pasture intake and grain supplementation on milk nitrogen fractions. Proceedings of the New Zealand Society of Animal Production 57, 154-156.

Robins C, Stockdale A, Crosby J, Morton J (2003) 'The condition magician: body condition scoring in dairy herds.' (Department of Natural Resources and Environment: Melbourne)

Rohrmoser G, Kirchgessner M (1982) The effect on milk yield and composition from cows of energetic undernutrition and subsequent realimentation. Zuchtungskunde 54(4), 276-287.

Thomson NA, Kay JK, Bryant MO (2001) Effect of stage of lactation on the efficiency of Jersey and Friesian cows at converting pasture to milk production or liveweight gain. Proceedings of the New Zealand Society of Animal Production 61, 213-216.

Visser S, Slangen CJ, Rollema HS (1991) Phenotyping of bovine milk proteins by reversed-phase high-performance liquid chromatography. Journal of Chromatography. A 548, 361-370. doi:10.1016/S00219673(01)88619-2

Walker GP, Dunshea FR, Doyle PT (2004) Effects of nutrition and management on the production and composition of milk fat and protein: a review. Australian Journal of Agricultural Research 55, 1009-1028. doi:10.1071/AR03173 